\title{
Aplikasi Enzim Ligninase dan Selulase untuk Meningkatkan Perkecambahan Benih Kelapa Sawit (Elaeis guineensis Jacq.) di Pusat Penelitian Kelapa Sawit, Pematang Siantar, Sumatera Utara
}

\author{
Apllication of Lignocellulose Enzyme to Improve Oil Palm Seed (Elaeis guineensis Jacq.) Germination in \\ Pusat Penelitian Kelapa Sawit, Pematang Siantar, North Sumatera
}

\author{
Putra K. Hadi, Eny Widajati", dan Selly Salma
}

\author{
Departemen Agronomi dan Hortikultura, Fakultas Pertanian, Institut Pertanian Bogor \\ (Bogor Agricultural University), Jl. Meranti, Kampus IPB Darmaga, Bogor 16680, Indonesia \\ Telp.\&Faks.62-251-8629353 e-mail agronipb@indo.net.id \\ *Penulis untuk korespondensi : enywidajati@yahoo.co.id
}

Disetujui 16 Januari 2017/ Published Online 24 Januari 2017

\begin{abstract}
The research was held in Pusat Penelitian Kelapa Sawit, Pematang Siantar, North Sumatra, started from March ${ }^{1 s t}$ until July ${ }^{24 t h}$ 2010. Focus activities is in breaking seed dormancy and seed germination division in PPKS. The Conclusions from this activities are: 1) In this research, two oil palm seed varieties tested responded differently to the treatments performed.; 2)In Yangambi seed variety, there are three application techniques of ligninase and cellulase enzymes that provide effective results with a real increase of Power Germination, Seed Maximum Growth Potential and Speed of Seed Growth and decrease Seed Index Dormancy. The third technique is $P_{1}$ with heating for 40 days, submersion in water (3 days), submersion with ligninase enzyme ( 1 day) and submersion with cellulase enzyme (for 2 days); $P_{2}$ by heating for 40 days, submersion with ligninase enzyme (1 day), submersion with cellulase enzyme (2 days) and submersion with water (3 days), and $P_{3}$ by heating for 40 days, submersion with the mixture of ligninase and cellulase enzyme (3 days) and submersion with water (3 days).; 3) In Langkat variety, application of ligninase and cellulase enzyme does not give significantly increase of Power Germination, Seed Maximum Growth Potential and decrease Seed Index Dormancy. In Speed of Seed Growth, the application of enzyme is only effective used to increase at $P_{2 .}$; 4) Aplication of ligninase and cellulase enzymes in Langkat varieties and Yangambi is proven can reduce the heating length of seeds in space heaters for 10 days in P4 and for 20 days treatment at P1, P2 and P3. 5) Application of lignoselulase enzyme on oil palm seeds do not cause symptoms of abnormalities in the seedlings.
\end{abstract}

Keywords : oil palm seed, lignocellulose enzyme, seed dormantion, germination seed

\section{ABSTRAK}

Penelitian ini dilakukan di Pusat Penelitian Kelapa Sawit, Pematang Siantar, Sumatera Utara, mulai dari 1 Maret hingga 24 Juli 2010. Fokus kegiatan ada pada divisi pematahan dormansi dan perkecambahan benih di PPKS. Kesimpulan dari kegiatan ini adalah: 1) Dua varietas benih kelapa sawit diuji responnya terhadap perbedaan perlakuan yang dilakukan .; 2) Benih varietas Yangambi, ada tiga teknik aplikasi enzim ligninase dan selulase yang memberikan hasil efektif dengan peningkatan nyata dari kekuatan tumbuh, potensi tumbuh maksimum, dan kecepatan tumbuh benih serta menurunkan indeks dormansi benih. Ketiga tekni tersebut adalah P1 dengan pemanasan selama 40 hari, perendaman air (3 hari), perendaman enzim ligninase (1 hari) dan perendaman enzim selulase (2 hari); 22 dengan pemanasan selama 40 hari, perendaman enzim ligninase (1 hari), perendaman enzim selulase (2 hari) dan perendaman air (3 hari), dan P3 dengan pemanasan selama 40 hari, perendaman campuran enzim ligninase dan selulase (3 hari) dan perendaman air (3 hari).; 3) Pada varietas Langkat, ligninase dan selulase tidak memberikan peningkatan signifikan pada kekuatan tumbuh benih, potensi tumbuh maksimum, dan menurunkan indeks dormansi benih. Pada kecepatan tumbuh benih, aplikasi enzim hanya efektif di P2.; 4) Aplikasi dari ligninase dan selulase enzim dalam varietas Langkat dan Yangambi terbukti dapat mengurangi panjang pemanasan biji di ruang pemanas selama 10 hari di P4 dan selama 20 hari perlakuan di P1, P2 dan P3.; 5) Aplikasi enzim lignoselulase pada bibit kelapa sawit tidak menyebabkan gejala kelainan pada bibit.

Kata kunci : benih kelapa sawit, dormansi benih, enzimligninase, perkecambahan benih 


\section{PENDAHULUAN}

Permintaan terhadap miyak kelapa sawit CPO (Crude Palm Oil) dan produk turunannya baik di dalam maupun luar negeri dari tahun ke tahun sangat tinggi, sehingga memiliki prospek pasar yang sangat menjanjikan. Hal inilah yang membuat perkebunan kelapa sawit di Indonesia sekarang diperluas secara besar-besaran, baik oleh perusahaan perkebunan negara, perusahaan besar swasta maupun mayarakat secara umum (Pardean, 2008).

Menurut data Direktorat Jenderal Perkebunan (2010), pada tahun 2007 luas areal perkebunan kelapa sawit di Indonesia mencapai 6 425061 ha dengan produksi 14151983 ton CPO (Crude Palm Oil) dan 2950503 ton minyak inti sawit atau PKO (Palm Kernel Oil). Pada tahun 2008, luas areal perkebunan kelapa sawit di Indonesia meningkat 5.45\% menjadi 6775196 ha dengan produksi CPO mencapai 15120644 ton (naik $6.84 \%$ ) dan 3150423 ton PKO (naik $6.78 \%$ ). Diperkirakan luas area perkebunan kelapa sawit tahun 2009 meningkat mencapai luas 7125331 ha (naik $5.17 \%$ ) dengan produksi CPO mencapai 16091500 ton (naik 6.42\%) dan 3350 825 ton PKO (naik $6.36 \%$ ).

Peningkatan luas areal pertanaman kelapa sawit yang terjadi saat ini juga diikuti oleh peningkatan permintaan terhadap benih kelapa sawit. Produsen benih di Indonesia pada tahun 2006 mampu menyuplai 141000000 kecambah. Produksi kecambah kelapa sawit pada tahun 2008 meningkat menjadi 151000000 kecambah, tetapi jumlah ini belum cukup untuk memenuhi kebutuhan kecambah kelapa sawit dalam negeri yang diperkirakan mencapai $230 \quad 000 \quad 000$ kecambah. Hal inilah yang membuat pemerintah melalui Departemen Pertanian membuka keran impor benih kelapa sawit dari luar negeri yang berasal dari DAMI Papua Nugini, ASD Kostarika, dan Malaysia (Pahan, 2008).

Pengadaan benih bahan tanaman kelapa sawit tidak semudah seperti pada tanaman lainnya. Kelapa sawit selama ini hanya dapat diperbanyak secara generatif dan baru dalam waktu beberapa tahun terakhir ini diketahui dapat diperbanyak secara vegetatif melalui tehnik kultur jaringan. Walaupun sudah didapat cara untuk memperoleh bahan tanam kelapa sawit secara vegetatif, tetapi karena metode ini masih sangat mahal maka pengadaan bahan tanam kelapa sawit sampai saat ini masih mengandalkan metode generatif (Lubis, 1993).

Upaya untuk meningkatkan produksi benih kelapa sawit secara generatif tidaklah mudah karena memiliki beberapa masalah, salah satunya dikarenakan benih kelapa sawit termasuk benih yang sulit dikecambahkan. Hal ini disebabkan oleh dormansi benih kelapa sawit yang lama. Lamanya dormansi benih kelapa sawit salah satunya disebabkan oleh struktur benih yang diselimuti cangkang yang keras dan impermeabel terhadap air dan udara. Hal ini mengakibatkan terhambatnya proses imbibisi air dan masuknya udara ke dalam benih sehingga perkecambahan benih juga menjadi terhambat.

Daya berkecambah benih kelapa sawit sangat rendah. Secara alami, dibutuhkan waktu \pm 1 tahun untuk perkecambahan dengan daya berkecambah hanya $40 \%$. Dengan teknik pematahan dormansi yang ada sekarang dengan perlakuan pemanasan 60 hari dan perendaman benih selama 10 hari, lama proses perkecambahan benih kelapa sawit dapat dipercepat sehinga hanya memerlukan waktu 4 bulan dengan persentase perkecambahan mencapai 75-80\% (Brahmana dan Chairani, 1997).Walaupun demikian, hal ini masih dirasa belum cukup karena masih memerlukan waktu yang lama yaitu 4 bulan.

Dinding sel benih kelapa sawit yang keras tersusun dari komponen penyusun utama berupa lignoselulosa. Lignoselulosa adalah suatu struktur komponen yang terdiri dari tiga komponen utama, yaitu lignin, selulosa dan hemiselulosa (Lynd et al., 2002). Perlakuan kimia dengan menggunakan bahan-bahan kimia sering dilakukan untuk memecahkan dormansi pada benih. Enzim selulase terbukti dapat mendegradasi komponen selulosa pada limbah padat kelapa sawit (Irawadi, 1991), sedangkan ligninase merupakan enzim yang dapat mendegradasi komponen lignin pada dinding sel tumbuhan (Aurora et al., 1992.). Aplikasi enzim ligninase dan selulase diharapkan dapat mempercepat proses perkecambahan dengan meningkatkan imbibisi air dan masuknya udara ke dalam benih.

Tujuan dari kegiatan ini yaitu untuk mempelajari proses kegiatan produksi benih kelapa sawit dari mulai pematahan dormansi sampai perkecambahan benih kelapa sawit serta untuk mengetahui pengaruh aplikasi enzim ligninase dan selulase terhadap perkecambahan benih kelapa sawit.

\section{METODE PENELITIAN}

Kegiatan penelitian dilaksanakan di Balai Besar Penelitian dan Pengembangan Bioteknologi dan Sumberdaya Genetik Pertanian, Bogor dan PPKS Marihat, Sumatera Utara.. Penelitian dilakukan selama 5 bulan, dimulai tanggal 1 
Maret hingga 24 Juli 2010. Bahan yang digunakan adalah benih kelapa sawit DxP varietas Langkat dan Yangambi, enzim ligninase, enzim selulase, fungisida (Dithane M-45) dengan bahan aktif Mankozeb $80 \%$, sterofom, label plastik, plastik PE, polibag $(14 \times 22 \mathrm{~cm})$, top soil, dan insektisida. Alat yang digunakan adalah gelas ukur, jaring plastik $(30 \times 15 \mathrm{~cm})$, tali, aerator, wadah plastik $(30 \times 25 \mathrm{~cm})$, bak perendaman, ember, rak pengering, heater ruangan, kipas angin, tray plastik, mikroskop dan alat-alat tulis.

Skema pelaksanaan percobaan dapat dilihat pada Gambar 1.

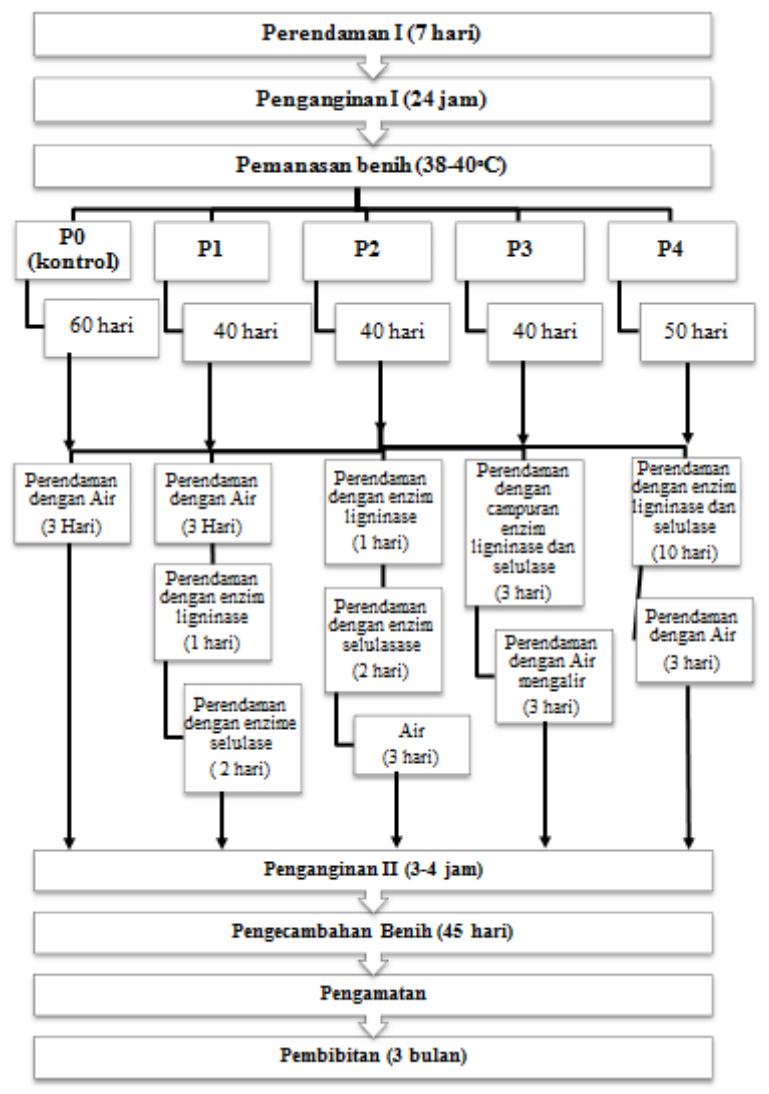

Gambar 1. Alur pelaksanaan percobaan

Percobaan ini disusun menggunakan rancangan kelompok lengkap teracak (RKLT) dengan dua faktor. Faktor pertama adalah varietas benih yaitu Langkat $\left(\mathrm{V}_{1}\right)$ dan Yangambi $\left(\mathrm{V}_{2}\right)$. Faktor ke dua adalah aplikasi enzim dengan 5 teknik aplikasi, yaitu :

\section{$\mathbf{P}_{\mathbf{0}}:\left(\mathbf{P}_{60} \mathbf{A}_{3}\right)$ Kontrol}

Pemanasan selama 60 hari, perendaman dengan air (3 hari)

$\mathbf{P}_{\mathbf{1}}:\left(\mathbf{P}_{\mathbf{4 0}} \mathbf{A}_{\mathbf{3}} \mathbf{L g}_{\mathbf{1}} \mathbf{S l}_{2}\right)$

Pemanasan selama 40 hari, perendaman dengan air (3 hari), perendaman dengan enzim ligninase ( 1 hari) dan perendaman dengan enzim selulase ( 2 hari)

$\mathbf{P}_{2}:\left(\mathbf{P}_{40} \operatorname{Lg}_{1} \mathrm{Sl}_{2} \mathrm{~A}_{3}\right)$
Pemanasan selama 40 hari, perendaman dengan enzim ligninase (1 hari), perendaman dengan enzim selulase ( 2 hari) dan perendaman dengan air (3 hari).

$\mathbf{P}_{3}:\left(\mathbf{P}_{40} \mathrm{LgSl}_{3} \mathrm{~A}_{3}\right)$

Pemanasan selama 40 hari, perendaman dengan campuran enzim ligninase dan selulase (3 hari), perendaman dengan air (3 hari)

$\mathbf{P}_{4}:\left(\mathbf{P}_{50} \operatorname{LgSl}_{10} \mathrm{~A}_{3}\right)$

Pemanasan selama 50 hari, perendaman dengan campuran enzim ligninase dan selulase (10 hari), perendaman dengan air (3 hari).

Jika didapatkan hasil yang berbeda nyata, maka dilakukan uji lanjut dengan menggunakan uji Duncan Multipel Range Test (DMRT), dengan a $5 \%$.

\section{Pelaksanaan}

Perendaman ke-1. Benih dari ruang stok yang masih dalam plastik dipindah ke dalam jaring untuk kemudian direndam dengan air yang mengalir. Perendaman dilakukan di dalam bak perendaman selama 7 hari . Di dalam bak perendaman aerator yang bertujuan memberikan oksigen untuk menghindari kondisi anaerob pada benih.

Penganginan ke-1. Setelah perendaman selama 7 hari, benih tersebut diangkat dari bak perendaman. Benih kemudian direndam dan dicuci dalam larutan fungisida (dithane M-45) dengan konsentrasi $0.2 \%$. Perlakuan ini dimaksudkan untuk membersihkan benih dari cendawan yang melekat pada benih. Setelah di treatment, benih dikeringkan pada rak-rak pengeringan selama \pm 24 jam sampai kadar air benih diperkirakan mencapai 17-18\%.

Pemanasan benih. Setelah dianginkan, proses selanjutnya benih dimasukkan ke dalam ruang pemanas selama 40, 50 dan 60 hari tergantung pada perlakuan percobaan yang diaplikasikan. Benih yang akan dimasukkan ke ruang pemanas terlebih dahulu dimasukkan ke tray plastik. Suhu diruang pemanas dikontrol agar suhu tetap antara $38-40^{\circ} \mathrm{C}$ dengan mengunakan heater dan kipas angin agar panas di ruang pemanas menyebar merata ke seluruh ruangan.

Perendaman ke-2. Setelah proses penyimpanan benih di ruang pemanas, benih pada tray plastik tersebut dimasukkan ke dalam jaring untuk dilakukan perendaman ke-2. Proses perendaman ke-2 sama dengan perendaman ke-1, tetapi pada perendaman ke-2 perendaman benih disesuaikan dengan perlakuan percobaan yang diaplikasikan. Pada perlakuan, dua jenis enzim ini dicampur dengan perbandingan 1:1. Perendaman benih dalam air mengalir dilakukan di bak 
perendaman, sedangkan perendaman benih dengan aplikasi enzim (ligninase maupun selulase) dilakukan pada wadah plastik yang dipasang aerator yang berfungsi untuk memberikan udara dan agar enzim terus mengalir didalam wadah.

Penganginan ke-2. Proses penganginan ke-2 sama dengan proses penganginan ke-1. Setelah diangkat dari perendaman, benih direndam pada larutan fugisida selama 3 menit. Kemudian, benih dianginkan pada rak-rak penganginan selama 3-4 jam sampai benih mencapai kadar air 22-23\%.

Pengecambahan benih. Benih dari rak pengeringan dimasukkkan ke dalam tray plastik yang kemudian dikirim ke ruang perkecambahan. Ruang perkecambahan memiliki suhu yang dipertahankan antara $28-32^{\circ} \mathrm{C}$ dengan $\mathrm{RH}$ 63$64 \%$. Jumlah benih setiap perlakuan adalah 100 butir, sehingga total digunakan 3000 benih. Sebelum benih dipindah ke tray plastik, tiap tray untuk yang digunakan untuk percobaan dibagi dengan disekat menggunakan sterofom.

Pengamatan. Pengamatan dilakukan terhadap: 1) Daya Berkecambah (DB), 2) Potensi Tumbuh Maksimum (PTM), 3) Kecepatan Tumbuh $\left(\mathrm{K}_{\mathrm{CT}}\right)$, 4) Indeks Dormansi (ID), dan 5) Keragaan Tumbuh Bibit. Pengamatan DB, PTM, $\mathrm{K}_{\mathrm{CT}}$ dan ID dilakukan 5 hari sekali. Pengamatan pertama dilakukan pada hari ke-5 setelah benih dimasukkan ke dalam ruang kecambah sampai hari ke-45. Pengamatan ini dilakukan untuk memisahkan kecambah normal, abnormal dan terserang cendawan. Kecambah diseleksi berdasarkan standar kecambah normal PPKS (Lubis, 1993), yaitu:

1. Kecambah tumbuh sempurna dan secara jelas dapat dibedakan antara radikula dan plumula

2. Plumula dan radikula tumbuh berlawanan arah

3. Panjang antara plumula dengan radikula $0.5-$ $2 \mathrm{~cm}$

4. Kecambah segar, tidak patah atau cacat dan tidak terserang cendawan

Pembibitan kecambah normal hasil seleksi. Pembibitan dilakukan terhadap kecambah normal hasil seleksi percobaan untuk melihat pengaruh enzim (ligninase dan selulase) yang diaplikasikan. Setiap ulangan perlakuan diambil 10 kecambah secara acak, sehingga total ada 300 kecambah yang dibibitkan. Pengamatan dilakukan terhadap keragaan tumbuh bibit untuk dilihat apakah ada ciri-ciri abnormal yang muncul. Bibit abnormal yang muncul dicatat ciri-cirinya dan dihitung jumlahnya.

\section{HASIL DAN PEMBAHASAN}

Berdasarkan hasil sidik ragam (Tabel 1) faktor tunggal aplikasi enzim menunjukkan pengaruh yang sangat nyata terhadap semua tolok ukur yang diamati yaitu $\mathrm{DB}, \mathrm{PTM}, \mathrm{K}_{\mathrm{CT}}$, dan ID. Faktor tunggal varietas tidak berpengaruh nyata terhadap semua tolok ukur yang diamati. Interaksi aplikasi enzim dengan varietas menunjukkan pengaruh yang sangat nyata terhadap tolok ukur daya berkecambah (DB), potensi tumbuh maksimum (PTM), kecepatan tumbuh $\left(\mathrm{K}_{\mathrm{CT}}\right)$, dan indeks dormansi (ID).

Tabel 1. Rekapitulasi hasil sidik ragam

\begin{tabular}{cccccc}
\hline \multirow{2}{*}{$\begin{array}{c}\text { Param } \\
\text { eter }\end{array}$} & $\begin{array}{c}\text { Aplika } \\
\text { si } \\
\text { Enzim }\end{array}$ & $\begin{array}{c}\text { Varieta } \\
\text { s }\end{array}$ & $\begin{array}{c}\text { Inter } \\
\text { aksi }\end{array}$ & $\begin{array}{c}\text { Ulanga } \\
\text { n }\end{array}$ & KK \\
\hline DB & $* *$ & tn & $* *$ & tn & 6.330 \\
PTM & $* *$ & tn & $* *$ & tn & 6.960 \\
$\mathrm{~K}_{\mathrm{CT}}$ & $* *$ & tn & $* *$ & tn & 8.730 \\
$\mathrm{ID}$ & $* *$ & tn & $* *$ & tn & 21.527
\end{tabular}

Keterangan: $\mathrm{tn}=$ tidak nyata; $*=$ nyata pada taraf $5 \%$; $* *=$ sangat nyata pada taraf $5 \%$

\section{Daya Berkecambah}

Hasil uji lanjut pada Tabel 2 menunjukkan DB tertinggi pada benih varietas Langkat didapat pada perlakuan $\mathrm{P}_{2}$ dan $\mathrm{P}_{3}$. Perlakuan $\mathrm{P}_{2}$ dan $\mathrm{P}_{3}$ menghasilkan DB yang sama yaitu $72.33 \%$ - $75.33 \%$ tetapi tidak berbeda secara nyata dibanding kontrol.

Tabel 2. Pengaruh perlakuan aplikasi enzim dan varietas terhadap daya berkecambah benih.

\begin{tabular}{cll}
\hline Perlakuan & $\begin{array}{c}\text { Langkat } \\
\ldots \%\end{array}$ & $\begin{array}{c}\text { Yangambi } \\
\ldots \%\end{array}$ \\
\hline P0 & $70.33 \mathrm{~cd}$ & $39.00 \mathrm{f}$ \\
P1 & $59.33 \mathrm{e}$ & $81.67 \mathrm{a}$ \\
P2 & $75.33 \mathrm{abc}$ & $78.00 \mathrm{ab}$ \\
P3 & $72.33 \mathrm{bc}$ & $80.67 \mathrm{a}$ \\
P4 & $64.67 \mathrm{de}$ & $69.67 \mathrm{~cd}$ \\
\hline
\end{tabular}

Keterangan: Angka yang diikuti huruf yang sama tidak berbeda nyata pada uji DMRT 5\%

Hasil ini menunjukkan bahwa aplikasi enzim pada benih varietas Langkat tidak efektif Hal ini diduga karena benih varietas Langkat 
memiliki ukuran yang kecil (diameter rata-rata benih $12.62 \mathrm{~mm}$ ) dengan susunan cangkang yang lebih kompak, keras dan lebih tebal. Hal ini mengakibatkat proses imbibisi air pada perlakuan kontrol dan perlakuan dengan aplikasi enzim tidak berbeda nyata yang dilihat dari DB masingmasing perlakuan benih.

Pada varietas langkat perlakuan $\mathrm{P}_{1}$ $\left(\mathrm{P}_{40} \mathrm{~A}_{3} \mathrm{Lg}_{1} \mathrm{Sl}_{2}\right)$ memiliki persentase $\mathrm{DB}$ paling rendah $(54.67 \%)$ dikarenakan terdapat $10.33 \%$ kecambah yang terserang cendawan sebelum masuk kriteria kecambah normal. Hal ini mengakibatkan walupun benih berkecambah tetapi tidak dapat dimasukkan kepada kriteria kecambah normal. Sedangkan pada kecambah yang terserang cendawan tetapi sudah termasuk kriteria kecambah normal, tetap dihitung dalam perhitungan DB.

Pada varietas Yangambi, DB tertinggi didapat pada perlakuan $\mathrm{P}_{1}, \mathrm{P}_{2}$ dan $\mathrm{P}_{3}$. Perlakuan $\mathrm{P}_{1}$, $\mathrm{P}_{2}$ dan $\mathrm{P}_{3}$ menghasilkan $\mathrm{DB}$ yang sama yaitu 78.00\%-81.67\% serta nyata lebih tinggi dibanding kontrol. Hasil ini menunjukkan bahwa aplikasi enzim pada benih varietas Yangambi dapat meningkatkan DB benih secara nyata. Peningkatan DB ini diduga karena degradasi ligninase oleh enzim ligninase dan selulosa oleh enzim selulose pada cangkang. Pada percobaan yang dilakukan oleh Irawadi (1991) pada limbah padat kelapa sawit, aplikasi enzim selulase selama 2 hari dapat mendegradasi $180 \mathrm{mg} / \mathrm{g}$ substrat selulosa atau 0,18\%. Aurora et al., (1992) menyatakan bahwa Jamur Pelapuk Putih atau Phanerochaete chrysosporium yang dapat memproduksi ligninase merupakan organisme yang paling umum digunakan dalam studi biodegradasi lignin. Pada percobaanya menunjukkan penggunaan $P$. chrysosporium selama 20 hari dapat mendegradasi $22 \%$ lignin pada lignin sintetik. Adanya degradasi lignin dan selulosa pada cangkang benih meningkatkan proses imbibisi air dan masuknya oksigen ke dalam benih sehingga meningkatkan perkecambahan benih.

Tabel 2 menunjukkan bahwa teknik aplikasi enzim terbaik pada benih varietas Yangambi yang dapat meningkatkan DB benih secara nyata adalah pada perlakuan $\mathrm{P}_{1}$ dengan pemanasan selama 40 hari; perendaman dengan air (3 hari), perendaman dengan enzim ligninase ( 1 hari) dan perendaman dengan enzim selulase (2 hari); $\mathrm{P}_{2}$ dengan Pemanasan selama 40 hari, perendaman dengan enzim ligninase (1 hari), perendaman dengan enzim selulase ( 2 hari) dan perendaman dengan air (3 hari); dan $\mathrm{P}_{3}$ dengan Pemanasan selama 40 hari, perendaman dengan campuran enzim ligninase dan selulase (3 hari), perendaman dengan air (3 hari).

Hasil DB pada kontrol varietas Yangambi yang rendah diduga akibat keadaan benih yang digunakan yaitu bagian intinya (kernel) sudah tidak menempel lagi dengan permukaan cangkang bagian dalam. Hal ini dapat diketahui dari ketika benih di goyang-goyangkan maka terdengar suara. Hal ini membuat benih menjadi sulit berkecambah karena imbibisi air hingga mencapai bagian embrio yang terdapat di dalam kernel akan menjadi lebih sulit dan memerlukan waktu yang lebih lama sehingga sampai akhir pengamatan banyak benih yang belum berkecambah.

\section{Potensi Tumbuh Maksimum}

PTM digunakan sebagai tolok ukur Viabilitas Total benih. Viabilitas Total benih adalah kemampuan benih untuk menunjukkan gejala hidup baik langsung oleh fenomena pertumbuhan maupun gejala metabolismenya. Jumlah kecambah yang dihitung pada PTM ini adalah semua kecambah normal dan abnormal.

Hasil uji lanjut pada Tabel 3 menunjukkan PTM tertinggi pada benih varietas Langkat didapat pada perlakuan $\mathrm{P}_{2}$ dan $\mathrm{P}_{3}$. Perlakuan $\mathrm{P}_{2}$ dan $\mathrm{P}_{3}$ menghasilkan DB yang sama yaitu $79.67 \%-81.00 \%$ tetapi tidak berbeda secara nyata dibanding kontrol. Hasil ini menunjukkan aplikasi enzim pada benih varietas Langkat tidak efektif, diduga karena benih varietas Langkat memiliki ukuran yang kecil (diameter rata-rata benih $12.62 \mathrm{~mm}$ ) dengan susunan cangkang yang lebih kompak, keras dan lebih tebal. Hal ini mengakibatkat proses imbibisi air pada perlakuan kontrol dan perlakuan dengan aplikasi enzim tidak berbeda nyata yang dilihat dari DB masingmasing perlakuan benih.

Tabel 3. Pengaruh perlakuan aplikasi enzim dan varietas terhadap potensi tumbuh maksimum (ptm) benih

\begin{tabular}{cll}
\hline Perlakuan & $\begin{array}{c}\text { Langkat } \\
\ldots \%\end{array}$ & $\begin{array}{c}\text { Yangambi } \\
\ldots \%\end{array}$ \\
\hline P0 & $78.00 \mathrm{bc}$ & $46.00 \mathrm{e}$ \\
P1 & $66.67 \mathrm{~d}$ & $87.33 \mathrm{a}$ \\
P2 & $81.00 \mathrm{ab}$ & $84.67 \mathrm{ab}$ \\
P3 & $79.67 \mathrm{abc}$ & $87.67 \mathrm{a}$ \\
P4 & $72.33 \mathrm{~cd}$ & $72.33 \mathrm{~cd}$ \\
\hline
\end{tabular}

Keterangan: Angka yang diikuti huruf yang sama tidak berbeda nyata pada uji DMRT 5\%

Pada varietas Yangambi, PTM tertinggi didapat pada perlakuan $\mathrm{P}_{1}, \mathrm{P}_{2}$ dan $\mathrm{P}_{3}$. Perlakuan $\mathrm{P}_{1}$, $\mathrm{P}_{2}$ dan $\mathrm{P}_{3}$ menghasilkan PTM yang sama yaitu 
$84.67 \%-87.67 \%$ serta nyata lebih tinggi dibanding kontrol. Hasil ini menunjukkan bahwa aplikasi enzim pada benih varietas Yangambi dapat meningkatkan PTM benih secara nyata. Peningkatan PTM ini diduga karena degradasi lignoselulosa pada cangkang benih oleh enzim ligninase dan selulose.

Tabel 3 menunjukkan bahwa teknik aplikasi enzim terbaik pada benih varietas Yangambi yang dapat meningkatkan PTM benih secara nyata adalah pada perlakuan $\mathrm{P}_{1}$ dengan pemanasan selama 40 hari; perendaman dengan air (3 hari), perendaman dengan enzim ligninase (1 hari) dan perendaman dengan enzim selulase (2 hari); $\mathrm{P}_{2}$ dengan Pemanasan selama 40 hari, perendaman dengan enzim ligninase (1 hari), perendaman dengan enzim selulase ( 2 hari) dan perendaman dengan air ( 3 hari); dan $\mathrm{P}_{3}$ dengan Pemanasan selama 40 hari, perendaman dengan campuran enzim ligninase dan selulase (3 hari), perendaman dengan air (3 hari).

Perbandingan PTM antar varietas memperlihatkan varietas Yangambi memiliki PTM rata-rata yang lebih besar dari pada PTM varietas Langkat pada perlakuan yang sama kecuali pada kontrol. Hal ini diduga karena tiga faktor, yaitu perbedaan varietas, ukuran benih dan keadaan benih varietas Yangambi yang sudah jelek yaitu bagian inti (kernel) sudah tidak menempel dengan bagian dalam cangkang benih.

\section{Kecepatan Tumbuh}

Tabel 4 menunjukkan bahwa pada benih varietas Langkat nilai $\mathrm{K}_{\mathrm{CT}}$ yang tertinggi didapat pada perlakuan $\mathrm{P}_{2}$ yaitu pemanasan selama 40 hari, perendaman dengan enzim ligninase (1 hari), perendaman dengan enzim selulase ( 2 hari) dan perendaman dengan air (3 hari).

Tabel 4. Pengaruh perlakuan aplikasi enzim dan varietas terhadapkecepatan tumbuh $\left(\mathrm{K}_{\mathrm{CT}}\right)$ benih

\begin{tabular}{cll}
\hline Perlakuan & $\begin{array}{c}\text { Langkat } \\
\ldots \%\end{array}$ & $\begin{array}{c}\text { Yangambi } \\
\ldots \%\end{array}$ \\
\hline P0 & $2.69 \mathrm{bc}$ & $1.24 \mathrm{e}$ \\
P1 & $2.23 \mathrm{~d}$ & $2.97 \mathrm{ab}$ \\
P2 & $3.16 \mathrm{a}$ & $2.68 \mathrm{bc}$ \\
P3 & $2.69 \mathrm{bc}$ & $2.96 \mathrm{ab}$ \\
P4 & $2.52 \mathrm{~cd}$ & $2.33 \mathrm{~cd}$ \\
\hline
\end{tabular}

Keterangan: Angka yang diikuti huruf yang sama tidak berbeda nyata pada uji DMRT 5\%

Perlakuan $\mathrm{P}_{2}$ memiliki hasil $\mathrm{K}_{\mathrm{CT}}$ yang nyata lebih tinggi dibanding kontrol. Peningkatan
$\mathrm{K}_{\mathrm{CT}}$ ini diduga karena degradasi lignin dan selulosa pada cangkang benih oleh enzim ligninase dan selulose. Rendahnya nilai $\mathrm{K}_{\mathrm{CT}}$ pada $\mathrm{P}_{1}$ disebabkan sebanyak $10.33 \%$ benih terserang cendawan.

Pada varietas Yangambi, $\mathrm{K}_{\mathrm{CT}}$ tertinggi didapat pada perlakuan $\mathrm{P}_{1}$ yaitu pemanasan selama 40 hari, perendaman dengan air (3 hari), perendaman dengan enzim ligninase (1 hari) dan perendaman dengan enzim selulase ( 2 hari). Perlakuan $\mathrm{P}_{1}, \mathrm{P}_{2}$ dan $\mathrm{P}_{3}$ menghasilkan nilai $\mathrm{K}_{\mathrm{CT}}$ yang sama yaitu $2.68 \%-2.97 \%$ serta nyata lebih tinggi dibanding kontrol.

Tabel 4 menunjukkan bahwa teknik aplikasi enzim terbaik pada benih varietas Yangambi yang dapat meningkatkan $\mathrm{K}_{\mathrm{CT}}$ benih secara nyata adalah pada perlakuan $\mathrm{P}_{1}$ dengan pemanasan selama 40 hari; perendaman dengan air (3 hari), perendaman dengan enzim ligninase (1 hari) dan perendaman dengan enzim selulase (2 hari); $\mathrm{P}_{2}$ dengan Pemanasan selama 40 hari, perendaman dengan enzim ligninase (1 hari), perendaman dengan enzim selulase ( 2 hari) dan perendaman dengan air ( 3 hari); dan $\mathrm{P}_{3}$ dengan pemanasan selama 40 hari, perendaman dengan enzim campuran enzim ligninase dan selulase (3 hari), perendaman dengan air (3 hari). Hasil ini menunjukkan bahwa aplikasi enzim pada benih varietas Yangambi dapat meningkatkan $\mathrm{K}_{\mathrm{CT}}$ benih secara nyata.

\section{Indeks Dormansi}

Indeks Dormansi (ID) digunakan sebagai tolok ukur Viabilitas Dormansi benih. ID benih adalah persentase benih yang tidak tumbuh sampai akhir pengamatan. Semakin kecil nilai ID, maka semakin baik karena semakin tinggi nilai perkecambahan benih.

Hasil uji lanjut pada Tabel 5 menunjukkan nilai ID terendah pada benih varietas Langkat didapat pada perlakuan $\mathrm{P}_{2}$ dan $\mathrm{P}_{3}$. Perlakuan $\mathrm{P}_{2}$ dan $\mathrm{P}_{3}$ menghasilkan nilai ID yang sama yaitu $19.00 \%-20.33 \%$ tetapi tidak berbeda secara nyata dibanding kontrol. Hasil ini menunjukkan aplikasi enzim pada benih varietas Langkat tidak efektif.

Pada varietas Yangambi, ID terendah didapat pada perlakuan $\mathrm{P}_{1}, \mathrm{P}_{2}$ dan $\mathrm{P}_{3}$. Perlakuan $\mathrm{P}_{1}$, $\mathrm{P}_{2}$ dan $\mathrm{P}_{3}$ menghasilkan ID yang sama yaitu $12.33 \%-15.33 \%$ serta nyata lebih rendah dibanding kontrol. Hasil ini menunjukkan bahwa aplikasi enzim pada benih varietas Yangambi efektif menurunkan ID benih secara nyata. Penurunan ID ini diduga karena degradasi lignoselulosa pada cangkang benih oleh enzim ligninase dan selulose. Adanya degradasi lignin 
dan selulosa pada cangkang benih meningkatkan proses imbibisi air dan masuknya udara ke dalam benih sehingga meningkatkan perkecambahan benih.

Tabel 5. Pengaruh perlakuan aplikasi enzim dan varietas terhadap indek dormansi (ID) benih

\begin{tabular}{cll}
\hline Perlakuan & $\begin{array}{c}\text { Langkat } \\
\ldots \%\end{array}$ & $\begin{array}{c}\text { Yangambi } \\
\ldots \%\end{array}$ \\
\hline P0 & $22.00 \mathrm{~cd}$ & $54.00 \mathrm{a}$ \\
P1 & $33.33 \mathrm{~b}$ & $12.67 \mathrm{e}$ \\
P2 & $19.00 \mathrm{de}$ & $15.33 \mathrm{de}$ \\
P3 & $20.33 \mathrm{cde}$ & $12.33 \mathrm{e}$ \\
P4 & $27.67 \mathrm{bc}$ & $27.67 \mathrm{bc}$ \\
\hline
\end{tabular}

Keterangan: Angka yang diikuti huruf yang sama tidak berbeda nyata pada uji DMRT 5\%

Tingginya nilai ID pada $\mathrm{P}_{0}$ varietas Yangambi diduga akibat keadaan benih yang digunakan sudah tidak baik yaitu bagian intinya (kernel) sudah tidak menempel lagi dengan permukaan cangkang bagian dalam.

Dilihat dari perbandingan antar varietas, varietas Yangambi memiliki $\mathrm{DB}$, PTM dan $\mathrm{K}_{\mathrm{CT}}$ yang lebih besar serta nilai ID yang lebih kecil dari varietas Langkat pada semua perlakuan kecuali pada kontrol. Hal ini diduga dapat terjadi karena tiga faktor, yaitu :

1. Perbedaan varietas yang memiliki sifat genotip dan fenotip yang berbeda.

2. Benih varietas Yangambi berasal dari pohon induk yang lebih tua sehingga memiliki ukuran benih yang lebih besar dari pada benih varietas Langkat. Diketahui bahwa benih pada tamanan kelapa sawit yang ukurannya lebih besar memiliki DB yang lebih tinggi bila dibanding benih yang kecil.

\section{Pengaruh Lama Pemanasan terhadap Perkecambahan Benih}

Aplikasi enzim ligninase dan selulase pada benih varietas Yangambi menunjukkan bahwa aplikasi enzim dapat meningkatkan perkecambahan benih secara nyata dilihat dari parameter DB, PTM, $\mathrm{K}_{\mathrm{CT}}$ yang meningkat nyata serta nilai ID yang menurun secara nyata. Hasil ini menunjukkan bahwa aplikasi enzim pada perlakuan $\mathrm{P}_{1}, \mathrm{P}_{2}, \mathrm{P}_{3}$ (dengan pemanasan 40 hari) dan $\mathrm{P}_{4}$ (pemanasan 50 hari) dapat mengurangi lama pemanasan di ruang pemanas selama 10-20 hari dari lama pemanasan yang normalnya 60 hari.

Pada benih varietas Langkat, walaupun percobaan menunjukkan hasil yang tidak berbeda nyata terhadap peningkatan perkecambahan benih yang dilihat dari DB, PTM, $\mathrm{K}_{\mathrm{CT}}$ dan ID benih, tetapi hasil ini menunjukkan bahwa aplikasi enzim pada perlakuan $\mathrm{P}_{1}, \mathrm{P}_{2}, \mathrm{P}_{3}$ (dengan pemanasan 40 hari) dan $\quad \mathrm{P}_{4} \quad$ (pemanasan 50 hari) dapat mengurangi lama pemanasan di ruang pemanas selama 10-20 hari dari lama pemanasan yang normalnya 60 hari.

\section{Keragaan Tumbuh Bibit}

Pengamatan dilakukan terhadap keragaan tumbuh bibit untuk dilihat apakah ada ciri-ciri abnormal yang muncul akibat perlakuan aplikasi enzim ligninase dan selulase. Bibit abnormal yang muncul dicatat ciri-cirinya dan dihitung jumlahnya. Setiap ulangan perlakuan diambil 10 kecambah secara acak, sehingga total ada 300 kecambah yang dibibitkan .

Setelah 5 minggu dibibitkan, dari 300 kecambah yang dibibitkan hanya terlihat satu bibit yang menunjukkan gejala abnormal, yaitu pada varietas Yangambi perlakuan $\mathrm{P}_{4}$ ulangan ke-1. Gejala abnormal ini diduga kuat akibat terserang hama serangga, yaitu semut. Hal ini menunjukkan bahwa aplikasi enzim ligninase dan selulase pada benih kelapa sawit tidak mengakibatkan munculnya gejala abnormalitas pada bibit.

\section{KESIMPULAN}

Pada penelitian ini dua varietas kelapa sawit yang diuji memberikan respon yang berbeda terhadap terhadap perlakuan yang dilakukan. Pada benih varietas Yangambi, terdapat 3 teknik aplikasi enzim ligninase dan selulase yang memberikan hasil efektif yang dengan nyata meningkatan DB, PTM dan $\mathrm{K}_{\mathrm{CT}}$ serta menurunkan nilai ID benih. Ke-3 teknik aplikasi enzim itu adalah $\mathrm{P}_{1}$ dengan pemanasan selama 40 hari, perendaman dengan air (3 hari), perendaman dengan enzim ligninase ( 1 hari) dan perendaman dengan enzim selulase (selama 2 hari); $\mathrm{P}_{2}$ dengan pemanasan selama 40 hari, perendaman dengan enzim ligninase ( 1 hari), perendaman dengan enzim selulase ( 2 hari) dan perendaman dengan air (3 hari); dan $\mathrm{P}_{3}$ dengan Pemanasan selama 40 hari, perendaman dengan campuran enzim ligninase dan selulase (3 hari), perendaman dengan air (3 hari). Pada varietas Langkat, aplikasi enzim ligninase dan selulase tidak secara nyata meningkatkan nilai DB, PTM dan ID. Pada nilai $\mathrm{K}_{\mathrm{CT}}$, aplikasi enzim hanya efektif digunakan untuk meningkatkan $\mathrm{K}_{\mathrm{CT}}$ benih pada $\mathrm{P}_{2}$ yaitu dengan pemanasan selama 40 hari, perendaman dengan enzim ligninase ( 1 hari), perendaman dengan enzim selulase ( 2 hari) dan perendaman dengan air (3 hari). Aplikasi enzim ligninase dan 
selulase pada benih varietas Langkat dan Yangambi terbukti dapat mengurangi pemanasan benih pada ruang pemanas selama 10 hari pada perlakuan $\mathrm{P}_{4}$ dan 20 hari pada perlakuan $\mathrm{P}_{1}, \mathrm{P}_{2}$ dan

\section{DAFTAR PUSTAKA}

Brahmana, J., M. Chairini. 1997. Pengadaan dan penyaluran kecambah kelapa sawit pusat penelitian kelapa sawit, hal. 1-10. Dalam K. Panin, Z. Poeloengan, P. Purba, T. Hutomo, P.L. Tobing, dan M.L. Fadli (Eds.). Posiding Pertemuan Teknis Kelapa Sawit, Pengenalan Bahan Tanaman Kelapa Sawit. PPKS. Medan.

Direktorat Jenderal Perkebunan. 2009. Produsen $\&$ varietas benih kelapa sawit. [internet] [diunduh 2009 Des 25] http//ditjenbun.deptan.go.id/images/ benih_sawit.pdf.

Direktorat Jenderal Perkebunan. 2010 a. Luas areal dan produksi perkebuanan seluruh Indonesia menurut pengusahaan. [internet] [diunduh 2010 Feb 02] http://ditjenbun.deptan.go.id/cigraph/inde x.php/viewstat/komoditiutama/8-Kelapa Sawit.

Irawadi, T.T. 1991. Produksi enzim ekstraselulase (selulase dan xilanase) dari Neurospora
$\mathrm{P}_{3}$. Aplikasi enzim ligninase dan selulase pada benih kelapa sawit tidak mengakibatkan munculnya gejala abnormalitas pada bibit.

sitophila pada substrat limbah padat kelapa sawit. Disertasi. Fakultas Pascasarjana IPB. Bogor. 235 hal.

Lubis, A. U. 1993. Pengadaan Benih Tanaman Kelapa Sawit (Elaeis guineensis Jacq.). Pusat Penelitian Kelapa Sawit. Medan. 65 hal.

Lynd, L. R., P. J. Weimer, W. H. van Zyl WH, I. S. Pretorius. 2002. Microbial Cellulose Utilization: Fundamentals and Biotechnology. Microbiol. Mol. Biol. Rev., 66(3): 506-577.

Pahan, I. 2008. Panduan Teknis Budidaya Kelapa Sawit. Jakarta(ID): PT. Indopalma Wahana Hutama.. 92 hal.

Pardean, M. 2008. Panduan Lengkap Pengelolaan Kebun dan Pabrik Kelapa Sawit. Jakarta(ID): PT. Agromedia Pustaka 226 hal.

Aurora, D.k., R. P. Elander, K. G. Mukerji. 1992. Handbook of Applied Mycology. CRC Prees. New York. 1114 p. 